\title{
A modified random oligonucleotide-based combination therapy for adjuvant treatment of pancreatic ductal adenocarcinoma
}

\author{
JUERGEN TEPEL $^{1}$, CHRISTINA MARCH ${ }^{1}$, THOMAS KETTERER ${ }^{3}$, MATTHIAS KAPISCHKE ${ }^{4}$, \\ ALEXANDER ARLT ${ }^{2}$, BERND KREMER ${ }^{1}$, HOLGER KALTHOFF ${ }^{1}$ and MARIE-LUISE KRUSE ${ }^{2}$ \\ Departments of ${ }^{1}$ General Surgery and Thoracic Surgery, and ${ }^{2}$ General Internal Medicine, \\ University Hospital Schleswig-Holstein, Campus Kiel, Kiel; ${ }^{3} \mathrm{CureVac}$ GmbH, Paul-Ehrlich-Strasse 15, \\ D-72076 Tübingen; ${ }^{4}$ Department of General and Vascular Surgery, Martin-Luther-Hospital, Schleswig, Germany
}

Received October 26, 2005; Accepted November 29, 2005

\begin{abstract}
Anti-cancer therapy in pancreatic ductal adenocarcinoma (PDAC) is mostly based on surgical removal or palliative therapy using antimetabolites, like 5'-fluorouracil or gemcitabine. Adjuvant treatment using these chemotherapeutics has recently proven a beneficial concept, though general survival rates are still poor. Most recently, combination therapy of gemcitabine with other targeted drugs was evaluated in clinical trials. We present here a study performed in a mouse orthotopic xenotransplant model of PDAC, using an oligonucleotide-based approach. We have shown previously that antisense oligonucleotides against p53 reduce the weight of orthotopic pancreatic tumours in immune-deficient mice. We further characterised terminal modifications of phosphorothioate oligonucleotides in vitro and found a random, unrelated control sequence carrying a D,L- $\alpha$-tocopherol modification at the $5^{\prime}$ and $3^{\prime}$ ends to be most efficient in induction of cell death in PancTu-1 cells. Modified random oligonucleotide (MRON) were thus further tested in vivo. MRON showed a reduction of tumour weight in established primary orthotopic tumours in SCID/bg mice. In a surgically adapted pre-clinical model, where primary tumours were resected and animals received adjuvant treatment, MRON was very efficient in suppression of relapse and metastasis, when combined with
\end{abstract}

Correspondence to: Professor Holger Kalthoff, Department of General Surgery and Thoracic Surgery, Molecular Oncology Section, University Hospital Schleswig-Holstein, Campus Kiel, Arnold-HellerStrasse 7, D-24105 Kiel, Germany

E-mail: hkalthoff@email.uni-kiel.de

Abbreviations: MRON, modified random oligonucleotide; PDAC, pancreatic ductal adenocarcinoma; ODN, oligodeoxynucleotide; $\mathrm{NF}-\kappa \mathrm{B}$, nuclear factor-кB; SCID/bg, severe combined immunodeficiency/beige mutation; scr, scrambled

Key words: oligonucleotide therapy, adjuvant treatment, pancreatic ductal adenocarcinoma gemcitabine. While the exact molecular mechanism of MRON activity still needs to be elucidated, the compound showed a remarkable preference for uptake into tumour cells in vivo.

\section{Introduction}

Ductal adenocarcinoma of the pancreas is currently the fifth leading cause of cancer-related deaths in the United States (1). Despite all efforts, which have been made to improve the efficacy of treatment, the prognosis of pancreatic adenocarcinoma remains poor. The only curative option consists of radical surgical resection with lymphadenectomy, by which a 5-year survival rate of 6-20\% (2-6) and, rarely, up to 30\% (7) can be achieved. But even if no detectable residual tumour is left behind (R0), there is a high rate of local recurrence, which accounts for $>70 \%$ of relapses (8). Therefore, the need for new therapeutic strategies is evident even for an adjuvant situation. One such new strategy would be to address genetic alterations associated with pancreatic adenocarcinoma. Mutation of the p53 tumour suppressor gene is one of the most frequent genetic alterations during development of malignancies $(9,10)$. Thus, an approach to address the expression and function of mutated p53, also representing gain of function mutations (11), in pancreatic adenocarcinoma using antisense oligonucleotides represents such a new therapeutic strategy. Antisense p53-based therapy has been used in the treatment of certain leukaemia (12). We have investigated a well-studied p53 antisense sequence, directed against exon 10 of the p53 gene, and have shown therapeutic effects in a murine orthotopic xenotransplant model (13). When studying the effectiveness of p53 antisense therapy, different terminal modifications of antisense oligonucleotides were designed to increase stability and cellular uptake. The differently modified p53 antisense oligodeoxynucleotides (ODN) were compared to scrambled p53 antisense sequences and an unrelated random control sequence. Tests were performed in vitro for impact on DNA synthesis and induction of apoptosis in PancTu-1 cells. Upon comparison of the results, the unrelated random sequence, carrying a double D, L- $\alpha$ tocopherol terminal modification, called MRON, proved to be most efficient and was thus investigated in more detail using a murine orthotopic xenotransplant model in vivo. 


\section{Materials and methods}

Laboratory animals. Four-week-old female SCID beige (SCID/bg) mice weighing 14-19 g were obtained from Charles River Laboratories (Sulsfeld, Germany). The mice were allowed to become acclimatized for 1 week in a sterile environment where bedding, food and water were autoclaved. Animal experiments and care were in accordance with the guidelines of the institutional authorities (no. 252-72241.121-7).

Cell culture. The cells used in this study were PancTu-1 $(14,15)$ human pancreatic adenocarcinoma cells. They were routinely cultured in RPMI-1640 medium (Invitrogen, Germany), supplemented with $10 \%$ heat-inactivated fetal calf serum (FCS, PAN-Systems, Aidenbach, Germany), $2 \mathrm{mM}$ glutamine, and $1 \mathrm{mM}$ sodium pyruvate (Invitrogen, Germany) (standard culture medium). The cells were maintained in monolayer culture at $37^{\circ} \mathrm{C}$ in a humid atmosphere with $5 \%$ $\mathrm{CO}_{2}$.

Synthesis of modified oligonucleotides. The sequences investigated were a 15 mer antisense-p53 sequence (5'-GCTC CCCCCT GGCT-3') and a scrambled random control (5'-CC TGCTTTCGCCCGT-3') which were modified with 3' addition of hexaethyleneglycol and $5^{\prime}$ addition of D,L- $\alpha$-tocopherol residues (HT-sequences) or 3' polyethyleneglycol of molecular weight of 1,500, and 5'-D,L- $\alpha$-tocopherol residues (PTsequences) or 5'3'-D,L- $\alpha$-tocopherol residues (TT-sequences). The sequence of the double D,L- $\alpha$-tocopherol-modified random control oligonucleotide, referred to as MRON, was (5'-CCTG TTGTTTTCTCT-3'). Modified oligodeoxynucleotides with phosphorothioate backbones were synthesized as described previously (13).

DNA-synthesis (methyl-[ $\left.{ }^{3} \mathrm{H}\right]$-thymidine-incorporation assay). Cells were plated in 96-well culture dishes (Nunc, Wiesbaden, Germany) at a density of 10,000 cells per well in standard culture medium. After $24 \mathrm{~h}$, the medium was replaced with medium containing only $0.5 \%$ FCS (starvation medium) and incubated for another $24 \mathrm{~h}$. Cells were then treated with 2.5 $\mu \mathrm{M}$ or $5 \mu \mathrm{M}$ ODN in medium with $0.5 \%$ FCS without transfection reagents for 24 or $48 \mathrm{~h}$. During the last $3 \mathrm{~h}$ of this period, a total amount of $7.4 \mathrm{kBq}$ methyl- $\left[{ }^{3} \mathrm{H}\right]$-thymidine (Amersham, Braunschweig, Germany) per well was added. Cells were harvested using a cell-harvester (Skatron, Lier, Norway) and incorporated radioactivity was determined by liquid scintillation counting.

DNA fragmentation assay (JAM-assay). Cells were plated in 96-well culture dishes at a density of 10,000 cells per well in standard culture medium. After $24 \mathrm{~h}$ medium was replaced by starvation medium and incubated for $24 \mathrm{~h}$. Cells were then metabolically labelled by addition of a total amount of $7.4 \mathrm{kBq}$ methyl- $\left[{ }^{3} \mathrm{H}\right]$-thymidine per well for $3 \mathrm{~h}$. Afterwards, cells were washed with PBS and subsequently treated with $2.5 \mu \mathrm{M}$ or $5 \mu \mathrm{M}$ ODN in medium with $0.5 \%$ FCS without transfection reagents for 24 or $48 \mathrm{~h}$. Cells were collected using a cellharvester and incorporated radioactivity was determined by liquid scintillation counting (16).
Electrophoretic mobility shift assay (EMSA). Nuclear extracts from MRON-stimulated PancTu-1 cells were prepared essentially as described previously (17).

Morphological analysis of in vivo distribution. For analysis of systemic distribution of MRON, $3 \mathrm{mg} / \mathrm{kg}$ Cy3-labelled MRON was administered i.p. to 2 tumour-bearing mice which were sacrificed 3 and $24 \mathrm{~h}$ after injection. Organ samples were frozen in liquid nitrogen and cryosections of 5-10 $\mu \mathrm{m}$ were prepared and post-fixed for $1 \mathrm{~h}$ in $2.5 \%$ paraformaldehyde. For reduction of autofluorescence, sections were treated with $1 \%$ sudan black in $70 \%$ ethanol and subsequently subjected to counterstain with bis-benzimide and Oregon Green 488labelled WGA as described previously (13). Analysis of tissue sections was carried out using a Zeiss Axiophot equipped with an Axiocam digital camera (Carl Zeiss Jena, Jena, Germany).

Orthotopic xenograft model. The human pancreatic adenocarcinoma cell line, PancTu-1, forms a highly invasive pancreatic adenocarcinoma when injected orthotopically into SCID/bg mice, as has also been described previously $(13,18)$. For orthotopic injection, PancTu-1 cells were trypsinized and suspended in serum-free RPMI-1640 medium and stored on ice. General anaesthesia was induced using fentanyl $(0.05 \mathrm{mg} /$ $\mathrm{kg})$, midazolam $(1 \mathrm{mg})$, medetomidin $(0.5 \mathrm{mg} / \mathrm{kg})$. A median laparotomy was performed and the pancreas identified. One million tumour cells (volume $30 \mu \mathrm{l}$ ) were injected into the body of the pancreas. The abdominal wall was closed using Vicryl 6/0 (Ethicon, Germany). The recovery was carefully supervised with red light re-warming and volume substitution. Tumour formation and growth was allowed for 8 days before the start of conservative therapy or tumour resection.

Conservative therapy of orthotopic tumours. Tumour-bearing mice were randomly assigned to either one of the different treatment or control groups. The mice in the treatment groups either received daily i.p. injection of the ODN or injections followed an interval scheme (alternating 3 days with and without treatment). Single doses varied from $1 \mathrm{mg} / \mathrm{kg}$ body weight (BW) per day up to $3 \mathrm{mg} / \mathrm{kg} \mathrm{BW}$ per day. Total doses ranged from $24 \mathrm{mg} / \mathrm{kg}$ up to $72 \mathrm{mg} / \mathrm{kg}$. The control group received a daily injection of $500 \mu \mathrm{l}$ PBS intra-peritoneally. Animals were sacrificed after 24 days of treatment (32 days after tumour cell inoculation). The tumours in the pancreas were removed and weighed, length, width and height were measured and the tumour volume was calculated using the formula recommended in a meta-analysis by Tomayko and Reynolds (19). Furthermore, organs were investigated for formation of metastases macroscopically and by histology of selected sections.

Adjuvant therapy of resected animals. Tumour resection was carried out essentially as described previously (20). Animals were allowed to recover from resection for 2 days before start of adjuvant therapy. Control animals received PBS i.p. MRON only was applied at $3 \mathrm{mg} / \mathrm{kg} \mathrm{BW}$ at 3 day intervals. Gemcitabine only was applied i.p. at $120 \mathrm{mg} / \mathrm{kg} \mathrm{BW}$ twice a week. Combined therapy of MRON and gemcitabine was $3 \mathrm{mg} / \mathrm{kg} \mathrm{BW}$ MRON at 3 day intervals with gemcitabine at $120 \mathrm{mg} / \mathrm{kg} \mathrm{BW}$ injected the day after MRON treatment. 


\section{A}

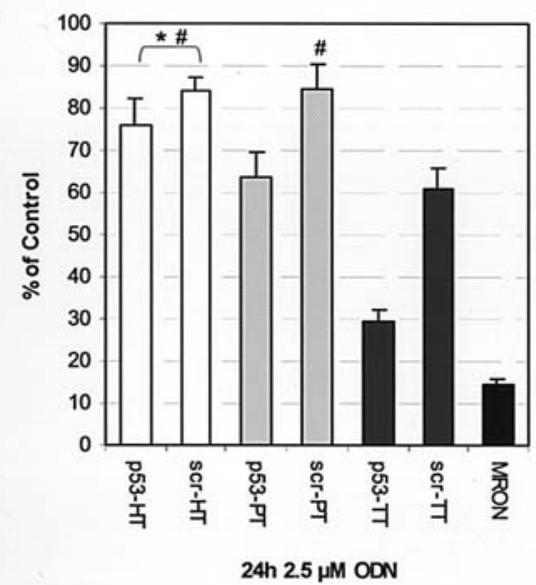

B

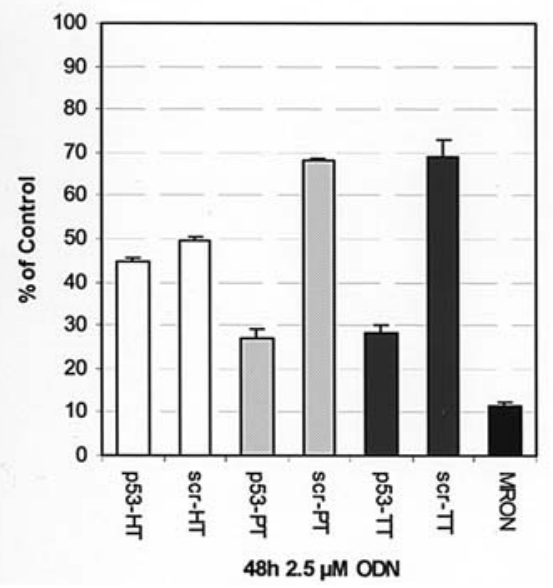

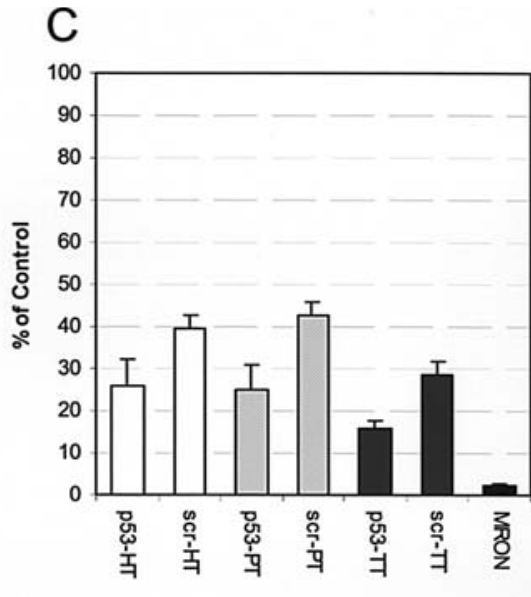

$24 \mathrm{~h} 5.0 \mu \mathrm{M}$ ODN

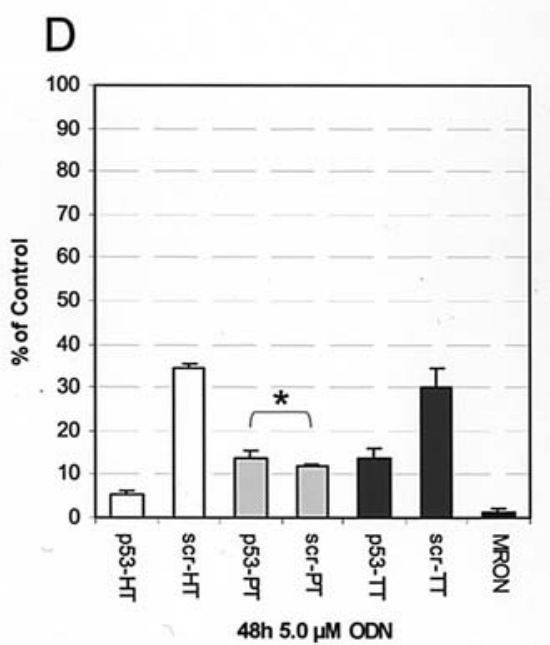

Figure 1. Effect of terminal modification of oligodeoxynucleotides (ODN) on DNA synthesis in PancTu-1 cells in vitro. Antisense p53 oligodeoxynucleotides (ODN) and scrambled p53-ODN bearing different terminal modifications were incubated at 2.5 and $5.0 \mu \mathrm{M}$ concentrations for 24 and $48 \mathrm{~h}$. p53-HT, antisense p53 with 3' hexaethyleneglycol, 5'-D,L- $\alpha$-tocopherol modification; scr, scrambled-p53-control sequence; PT, 3' polyethylene1500, 5'-D,L- $\alpha$-tocopherol; and TT, 5'3'-D,L- $\alpha$-tocopherol modification. Data are presented as \% of control values ("no significance between antisense and scrambled control sequence, " no significance against untreated control, for all other p-values see Results).

Statistics. In vitro data were analysed for homogeneity of variance (ANOVA) using the Levene test. In case of heterogeneity of variance, post-hoc test Dunnett T3 was employed for analysis of significance. In vivo data were subjected to Student's t-test.

\section{Results}

Efficiency of inhibition of DNA synthesis by modified oligodeoxynucleotides depends on terminal modifications. To test for influence of terminal modification of phosphorothioate ODNs, four different sets of terminal modifications were investigated. For comparison, a previously described p53 anti-sense $15 \mathrm{mer}$ (13) was compared to scrambled p53 antisense ODN. These sequences were modified by $3^{\prime}$ hexaethyleneglycol and 5'-D,L$\alpha$-tocopherol residues (HT), 3' polyethylene-glycol1500 and 5'$\mathrm{D}, \mathrm{L}-\alpha$-tocopherol modification (PT), or 3'5'-D,L- $\alpha$-tocopherol (TT) modification. To test for sequence independence, an unrelated random oligonucleotide was designed and used in its double-tocopherol (TT) modified variant, MRON. The effects on DNA synthesis were analysed by $\left[{ }^{3} \mathrm{H}\right]$-thymidineincorporation assays, which were performed in PancTu-1 cells at concentrations of 2.5 and $5.0 \mu \mathrm{M}$ for 24 and $48 \mathrm{~h}$. As shown in Fig. 1A, p53-HT-ODN reduced DNA synthesis less efficiently than p53-PT-ODN and p53-TT-ODN. Remarkably, for scrambled-p53-sequences (scr-p53-sequences), notable effects on DNA synthesis were seen, a significant reduction of DNA synthesis as compared to untreated controls ( $p>0.02$, post-hoc test Dunnett T3) was found for all ODNs except scrp53-HT and scr-p53-PT ODN at $2.5 \mu \mathrm{M}$ for $24 \mathrm{~h}$. The highest efficiency after $24 \mathrm{~h}$ at a $2.5-\mu \mathrm{M}$ concentration was found for MRON. After 24-h treatment with a 5.0- $\mu \mathrm{M}$ ODN concentration, the inhibition was more pronounced for all different modifications as well as for all tested sequences, as seen in Fig. 1C. This dose-dependent effect was even higher than the time-dependent effect of a $2.5-\mu \mathrm{M}$ concentration of ODN after $48 \mathrm{~h}$, as seen in Fig. 1B. Prolonged incubation appears to strengthen inhibitory effects for PT and TT modifications of anti-p53-ODNs. Surprisingly, MRON was the most efficient in inhibition of DNA synthesis among all ODNs tested. Besides MRON, efficiency of inhibition of DNA synthesis was significantly higher for p53 antisense ODNs compared to scrambledp53-sequences ( $\mathrm{p}>0.001$, Dunnett), except for $24-\mathrm{h} 2.5-\mu \mathrm{M}$ HT modification and $48-\mathrm{h} 5.0-\mu \mathrm{M}$ PT modification. 

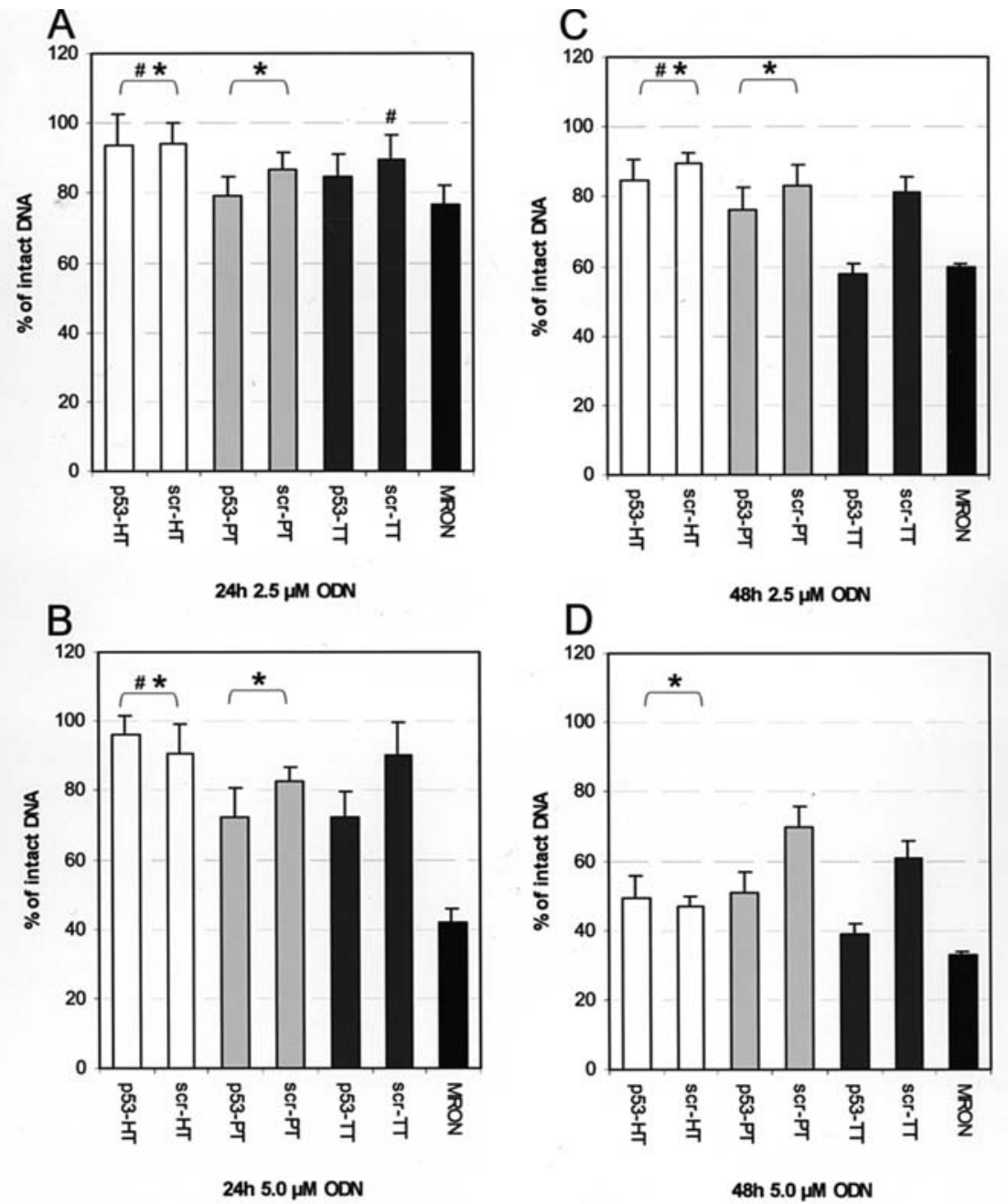

Figure 2. Effect of terminal modification of oligodeoxynucleotides (ODN) on DNA fragmentation in PancTu-1 cells in vitro. Antisense p53 oligodeoxynucleotides (ODN) and scrambled p53-ODN bearing different terminal modifications were incubated at 2.5- and 5.0- $\mu \mathrm{M}$ concentrations for 24 and $48 \mathrm{~h}$. Data are presented as \% of intact DNA ("no significance between antisense and scrambled control sequence, " no significance against untreated control, for all other p-values see Results).

Induction of apoptosis by modified oligodeoxynucleotides is time- and dose-dependent. Induction of apoptosis was analysed by means of DNA fragmentation as determined by JAM-assay. A significant impact was documented for antisense p53 carrying PT and TT modifications and MRON compared to untreated controls ( $>00.05$, TukeyHSD/Dunnett T3). Prolonged incubation with a $2.5-\mu \mathrm{M}$ concentration for $48 \mathrm{~h}$ enhanced DNA fragmentation for double-tocopherol modified ODNs but appeared to be unrelated to sequence, with antisense-p53-TT as efficient as MRON (approximately $40 \%$ reduction of intact DNA) (Fig. 2C). Treatment with 5.0- $\mu \mathrm{M}$ ODN for $48 \mathrm{~h}$ showed the most efficient impact on DNA stability, although the effect appeared to be sequence independent, as scrambled p53-ODNs are as potent as p53 antisense ODNs. HT-modified ODNs showed no significant induction of DNA fragmentation at low doses. Even at high concentrations, only $48 \mathrm{~h}$ of incubation yielded a significant effect. PT modification of ODNs always resulted in significant effects compared to controls, but only at high concentrations and $48 \mathrm{~h}$ of incubation were significant differences found between antisense and scrambled sequence ( $p>0.005$, Dunnett T3). In all settings, MRON showed the highest efficiency of all tested modified ODNs.

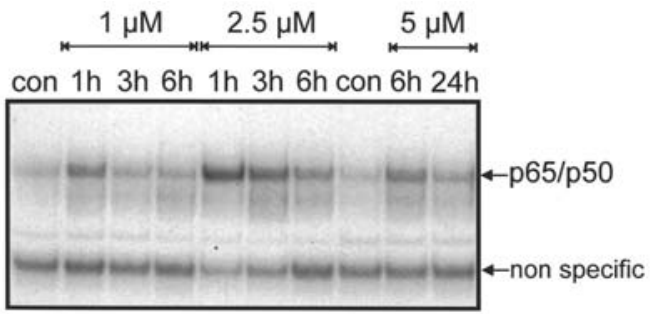

Figure 3. Gel shift analysis of NF-кB activity in cells stimulated with MRON. PancTu-1 cells were treated with 1.0- and 2.5- $\mu \mathrm{M}$ MRON for 1-, 3-, and 6-h treatment with 5.0- $\mu \mathrm{M}$ MRON was carried out for 6 and $24 \mathrm{~h}$.

MRON activates $N F-\kappa B$ in vitro. To test for a mechanism of MRON activity, we performed gel shift analysis (EMSA) of PancTu-1 cells stimulated with MRON at concentrations of $1.0,2.5$ and $5.0 \mu \mathrm{M}$ for different times. Fig. 3 shows a representative analysis revealing an induction of NF- $\mathrm{kB}$ after $1 \mathrm{~h}$ of incubation with $1.0-\mu \mathrm{M}$ MRON. After 3 and $6 \mathrm{~h}$, $\mathrm{NF}-\kappa \mathrm{B}$ activity returns to control levels. When cells were incubated with 2.5- $\mu \mathrm{M}$ MRON, the induction of NF-кB was stronger and remained above control levels even after $6 \mathrm{~h}$. 

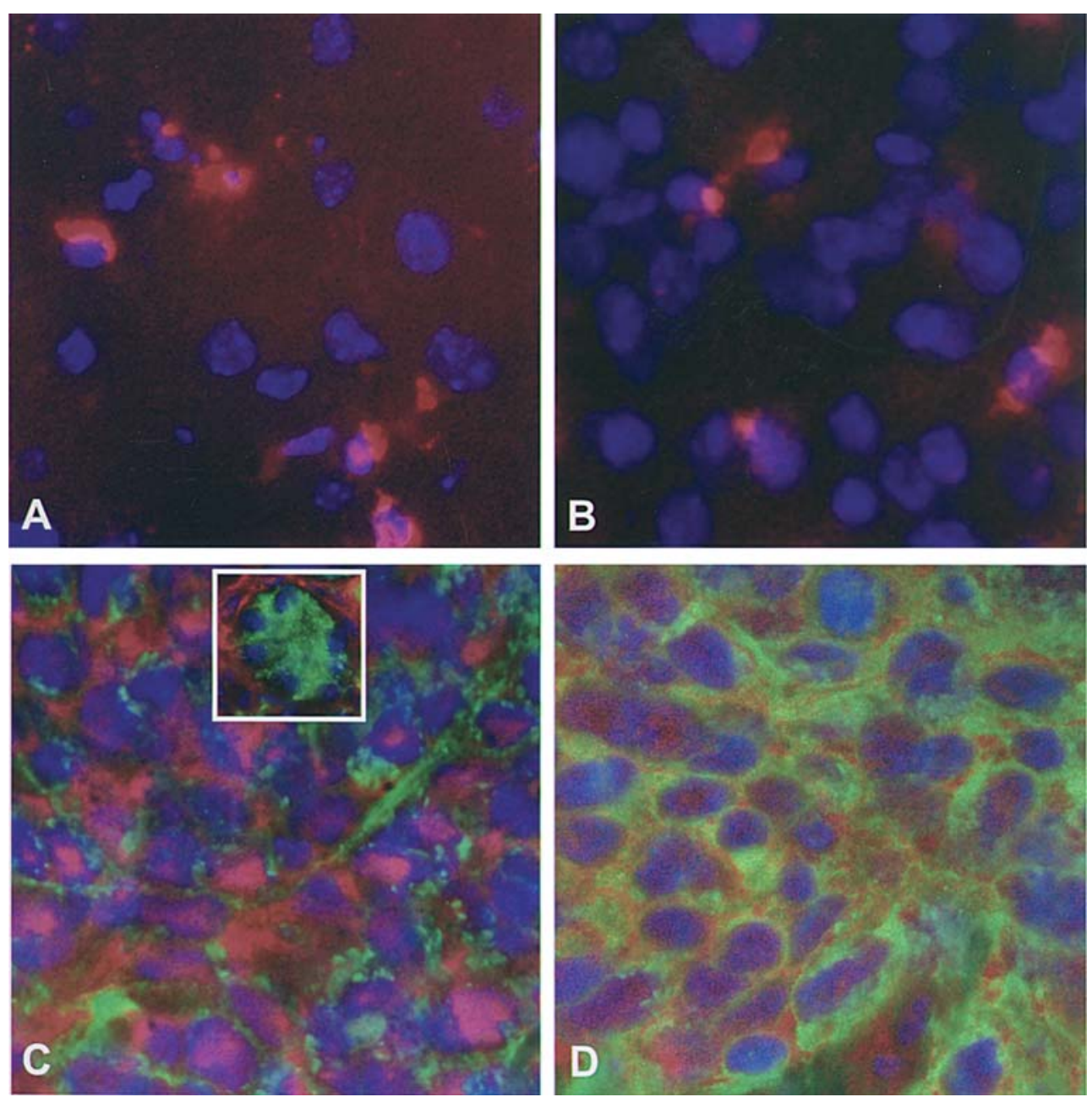

Figure 4. In vivo distribution and uptake of Cy3-labelled MRON in tumour-bearing mice. Cy3-labelled MRON is depicted in red, nuclei are blue and WGAstaining is seen in green. (A) Shows uptake of MRON (red) in the liver after $3 \mathrm{~h}$. (B) Shows uptake in the liver after $24 \mathrm{~h}$. (C) Shows uptake of Cy3-labelled MRON (red) into tumour cells, the inset shows an acinus with WGA-stained zymogen granules (green), surrounded by Cy3-MRON (red) labelled interstitial cells. (D) Shows uptake in tumour cells after $24 \mathrm{~h}$.

Induction of NF- $\kappa \mathrm{B}$ by incubation with $5.0-\mu \mathrm{M}$ MRON was visible after $6 \mathrm{~h}$ and returned to control levels after $24 \mathrm{~h}$. Rapid, dose-dependent induction of NF- $\kappa \mathrm{B}$ activity within $1 \mathrm{~h}$ of treatment and subsequent decrease of NF- $\kappa \mathrm{B}$ activity points towards a specific effect targeting NF-кB in PancTu-1 cells, arguing for a receptor-mediated mechanism of MRON activity in PancTu-1 cells.

MRON shows a preference for tumour cells in vivo. To test for in vivo uptake of MRON into cells, tumour-bearing mice were injected with Cy3-labelled MRON, and sacrificed after 3 and $24 \mathrm{~h}$ of treatment. After $3 \mathrm{~h}, \mathrm{Cy} 3-\mathrm{MRON}$ was found enriched in all organs investigated; intraperitoneal organs, such as the colon and spleen, and extraperitoneal organs, such as the lung and heart (data not shown).

Closer investigation of the liver, as shown in Fig. 4A and B, revealed that non-parenchymal cells were heavily labelled with Cy3-MRON after $3 \mathrm{~h}$ of treatment, while hepatocytes showed only diffuse uptake (Fig. 4A). After 24 h, Cy3-label was reduced in hepatocytes and less intense in non-parenchymal liver cells (Fig. 4B). Orthotopic tumours in the pancreas were identified by WGA-staining, as WGA has a strong affinity to the plasma membrane of tumour cells, while it binds to zymogen granules in pancreatic acinar cells. Fig. 4C shows tumour cells as outlined in green with strong labelling of Cy3-MRON throughout the cell and the nucleus. The inset shows an acinus with central green WGA-label in the acinar cells and surrounding Cy3-MRON-staining, due to uptake into interstitial, periacinar cells, which was typical for normal pancreatic tissue (data not shown). Twenty-four hours after injection of Cy3-MRON, the labelling of tumour cells as seen in Fig. 4D was reduced, as also seen in the liver (compare Fig. 4B). These findings suggest that MRON is rapidly distributed after intraperitoneal injection and uptake into organs and cells is efficient. Moreover, there appears to be a preferential uptake into interstitial cells and tumour cells in contrast to parenchymal cells as shown for liver and pancreas.

Effects of MRON in a murine orthotopic xenotransplant model. Effectivity of MRON in vitro as an anti-tumour agent was then tested in vivo in a murine orthotopic xenotransplant model. PancTu-1 cells were injected orthotopically into the pancreas of SCID/bg mice and tumour formation was allowed for 8 days prior to the start of therapy. In a first experiment, the efficacy of MRON was tested with regard to different doses and application regimes over a period of 3 weeks on 


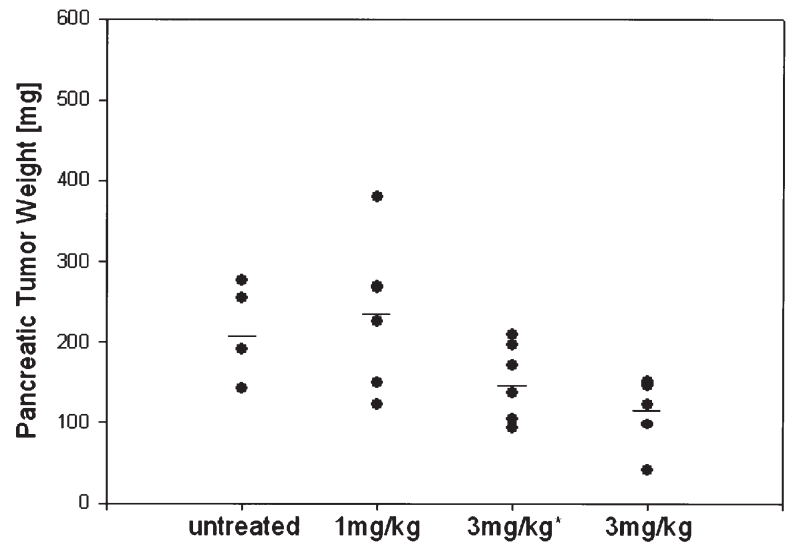

Figure 5. Effect of MRON in vivo. Conservative therapy of established orthotopic tumours (7 days after orthotopic inoculation of tumour cells) in SCID/bg mice: untreated (500 $\mu 1$ PBS i.p. daily; $\mathrm{n}=4), 1 \mathrm{mg} / \mathrm{kg}$ ( $1 \mathrm{mg} \mathrm{MRON} / \mathrm{kg} \mathrm{BW}$ i.p. daily; $\mathrm{n}=6$ ), $3 \mathrm{mg} / \mathrm{kg}^{*}$ ( $3 \mathrm{mg}$ MRON$/ \mathrm{kg} \mathrm{BW}$ in 3 day intervals; $\mathrm{n}=6$ ) and $3 \mathrm{mg} / \mathrm{kg}$ ( $3 \mathrm{mg}$ MRON$/ \mathrm{kg}$ BW i.p. daily; $\mathrm{n}=6$ ). Differences of pancreatic tumour weight did reach statistical significance between untreated and $3 \mathrm{mg} / \mathrm{kg}$ $(\mathrm{p}=0.016)$.

Table I. Effects of adjuvant treatment after resection of orthotopic PDAC in mice.

\begin{tabular}{lcc}
\hline & Local recurrence & Metastases \\
\hline $\begin{array}{l}\text { Resected animals, } \\
\text { untreated }\end{array}$ & $8 / 8$ & $7 / 8$ \\
$\begin{array}{l}\text { Adjuvant treatment } \\
\text { with MRON }\end{array}$ & $6 / 8$ & $7 / 8$ \\
$\begin{array}{l}\text { Adjuvant treatment } \\
\text { with gemcitabine }\end{array}$ & $3 / 8$ & $1 / 8$ \\
$\begin{array}{l}\text { Adjuvant treatment with } \\
\text { gemcitabine and MRON }\end{array}$ & $0 / 8$ & $0 / 8$ \\
\hline
\end{tabular}

established tumours as a conservative treatment. Fig. 5 shows the distribution of pancreatic tumour weight for conservative treatment of established tumours. The weight of untreated tumours ranges closely around a mean of $217 \mathrm{mg}$. When treated with a daily dose of $1 \mathrm{mg} / \mathrm{kg} \mathrm{BW}$ of MRON, the mean tumour weight was $236 \mathrm{mg}$ with a spread of individual weights from $380 \mathrm{mg}$ to $123 \mathrm{mg}$. Daily treatment with $3 \mathrm{mg} / \mathrm{kg} \mathrm{BW}$ of MRON reduced the mean tumour weight significantly ( $\mathrm{p}=0.016)$ to $118 \mathrm{mg}$. Furthermore, the individual tumour weight was rather homogenous, arguing for sensitivity of preformed tumours towards this dosage of MRON. When applied at a 3 day interval at a dosage of $3 \mathrm{mg} / \mathrm{kg} \mathrm{BW}$, MRON reduced the mean tumour weight to $152 \mathrm{mg}$, representing a $30 \%$ reduction; however, this was not statistically significant $(\mathrm{p}=0.098)$. Higher individual dosages of MRON at $6 \mathrm{mg} / \mathrm{kg}$ BW did not improve the reduction of tumour weight, while increasing side-effects (data not shown).

Table I summarises the effect of adjuvant treatment after tumour resection using MRON, gemcitabine or a combination of both. Animals, which were resected but left untreated, showed $100 \%$ local recurrence, and 7 out of 8 animals had metastasis formation. Adjuvant treatment with MRON at a dosage of $3 \mathrm{mg} / \mathrm{kg} \mathrm{BW}$ at 3 day intervals resulted in 2 animals showing no local recurrence and 7 out of 8 animals with metastases. Adjuvant treatment with gemcitabine resulted in local recurrence in 3 animals and liver metastasis in 1 animal. Adjuvant treatment with a combination of MRON and gemcitabine showed no local recurrence and no metastases, resulting in 8 out of 8 animals without detectable tumours or metastases.

\section{Discussion}

In vivo application of antisense oligonucleotides in animal models has always suffered from the critique that the antisenseeffect was not properly documented (21). We have shown before that p53 antisense oligonucleotides reduced the level of p53 expression in vitro (22) and had an inhibitory effect on tumour development, when applied in vivo (13). The study presented here shows that the effectivity of oligonucleotides was strongly affected by their terminal modification. Depending on the length and lipophilic properties of terminal modifications, the apoptotic effectiveness is strongly enhanced in vitro. The most effective terminal modification proved to be a 5'3'-D,L- $\alpha$-tocopherol residue, in all examined parameters in vitro. A totally sequence-independent random control oligonucleotide with 5'3'-D,L- $\alpha$-tocopherol modification was the most effective agent in vitro. MRON was further tested in vivo for its effect on established orthotopical pancreatic tumours and in a clinically adapted resection model for adjuvant therapy.

In vivo testing of MRON on established orthotopic tumours, resembling conservative or palliative therapy in humans, revealed a dose-dependent reduction of tumour size. At a dosage of $3 \mathrm{mg} / \mathrm{kg} \mathrm{BW}$, the pancreatic tumour weight showed a higher homogeneity of distribution around the mean, which argues for the effectivity of MRON at this dosage in vivo. At higher concentrations of $6 \mathrm{mg} / \mathrm{kg} \mathrm{BW}$, no further effect was seen regarding reduction of tumour size and the animals did not tolerate higher dosages as well. However, at lower concentrations of $1 \mathrm{mg} / \mathrm{kg} \mathrm{BW}$, there was a marked heterogeneity of tumour size with a higher mean than untreated controls. This finding points towards the dose-dependent differential activity of MRON. A slight growth-promoting effect was also observed in vitro, when MRON was used at the low dosage of $1 \mu \mathrm{M}$ (data not shown). Application of MRON at $3 \mathrm{mg} / \mathrm{kg}$ $\mathrm{BW}$ in adjuvant therapy employing our model of tumour resection (20) resulted in 2 animals without local recurrence, but generally the range of weight of local recurrence showed a very different reactivity of individual animals towards treatment. This finding was suggestive of a differential reactivity of dormant tumour cells after resection-induced activation towards MRON. Obviously, quite similar to the human situation of relapse after $\mathrm{R} 0$ resection of pancreatic ductal adenocarcinoma, some cells remain dormant and are activated by surgical trauma. These cells which give rise to local recurrence are most likely to have characteristics different from the tumour cells which make up the resected tumour mass. A combination therapy of MRON with gemcitabine, a well established chemotherapeutic agent was tested as well. 
Gemcitabine is well known to effectively reduce pancreatic tumour weight in mice (20). However, during therapy with gemcitabine alone, 3 animals out of 8 showed local recurrence and liver metastasis. Combinational adjuvant therapy with MRON and gemcitabine not only inhibited local recurrence in all animals treated, but also inhibited formation metastases, thus combination of MRON and gemcitabine proved to be more effective than gemcitabine as monotherapy.

Investigating the molecular mechanism of MRON activity, we analysed NF- $\mathrm{BB}$ activity. It has been demonstrated that PDAC shows enhanced constitutive activity of NF- $\kappa \mathrm{B} / \mathrm{RelA}$ $(17,23)$. Constitutive activity appears to play an essential role in resistance of PDAC against gemcitabine (24) and metastasis (25). In PancTu-1 cells, displaying a moderate constitutive NF$\kappa \mathrm{B}$ activity, MRON further activated NF- $\mathrm{BB}$ activity in a dosedependent manner, low doses induced a slight, short increase in DNA binding, while higher doses of MRON induced a stronger signal that lasted longer and, thus, might induce a different set of target genes (26) than a short burst of activity. This is supported by the observation that low doses of MRON have no effect on DNA damage but slightly induce proliferation, while high doses of MRON induce a strong inhibition of DNA synthesis and subsequently DNA fragmentation. One possible explanation for the observed combination effects might be the induction of cyclins (27) accelerating the cell cycle, thus raising the susceptibility of cells to anti-metabolites.

In humans, gemcitabine has been established as a new standard treatment for patients with advanced pancreatic cancer (28). Besides a significant improval in clinical benefit response, median survival is only modestly prolonged to approximately 6 months (29). Lately, a multi-centre study (ESPAC I) has shown a significant survival effect of adjuvant treatment with 5'-fluorouracil after pancreatic resection (30). Currently, an ongoing trial (ESPAC II) evaluates the potential of gemcitabine to reduce local recurrence and systemic relapse in the same adjuvant setting. Our studies, employing the clinically adapted model of resection of orthotopic pancreatic tumours (20) clearly support the absolute need for adjuvant therapy. In this study investigating a new oligonucleotidebased substance for treatment of pancreatic adenocarcinoma we found a definite synergistic activity between MRON and gemcitabine, even if MRON alone was by far not as efficient in mice as gemcitabine. As to the molecular mechanism of MRON activity, uptake experiments in tumour-bearing mice have shown a selectivity of MRON for tumour cells and interstitial cells. In normal mouse pancreas, MRON is clearly enriched in interstitial fibroblast-like cells (data not shown). In tumour-bearing mice, MRON is enriched in interstitial fibroblast-like cells surrounding acini and in the tumour cell mass. Furthermore, Cy3-labelled MRON accumulates in the cytoplasm and nuclei of tumour cells. Investigation of the liver revealed that uptake into hepatocytes is by far not as efficient as into interstitial cells. This finding argues for differential uptake mechanisms for MRON (or modified oligonucleotides in general, as we have shown previously). One mechanism might be passive uptake via pinocytosis, i.e. an unaided traversal across the plasma membrane, which would account for diffuse labelling as observed in hepatocytes. But the striking selectivity of labelling in interstitial cells and tumour cells versus parenchymal cells of the pancreas and liver argues for a receptor-based activity and cellular entry, which cannot be explained by phagocytosis as MRON is soluble, not particulate. As orthotopic tumours of PancTu- 1 cells in mice do not induce a profound desmoplastic reaction, they do not build up an encapsulated environment restricting flow of Cy3-MRON. In vivo uptake experiments showed biological availability and stability. Cellular staining was pronounced after $3 \mathrm{~h}$ of treatment and started to fade after $24 \mathrm{~h}$ of systemic application; thus, MRON is effectively delivered to orthotopical tumours.

Recent research on combinational therapy of pancreatic tumours employing chemotherapeutical drugs with agents directly addressing molecular targets clearly indicates the way forward. It is most unlikely that a single agent can address the variety of escape mechanisms that tumour cells have developed, but combined activation of different cellular signalling pathways and responses appears to be a more effective method of anti-tumour therapy (31). MRON appears to target signalling pathways which are likely to activate tumour cells, which are then hit more efficiently by a second strike with the metabolic blockade introduced by gemcitabine. This appears to have a profound effect on aggressively growing activated residual tumour cells after resection. Obviously further investigation is needed regarding molecular mechanisms and optimal combinations of MRON with other therapeutic agents, but a relative selectivity towards certain cell types is a promising aspect of modified oligonucleotide-based antitumour agents beyond antisense strategies.

\section{Acknowledgements}

This work was supported by a BMBF grant given to H.K. and the late Professor E. Bayer and, furthermore, by grants from the 'Hensel Stiftung' and 'Schleswig-Holsteinische Krebsgesellschaft' to J.T. We want to thank S. Erdogan, A. Duttmann and D. Emme for their excellent technical assistance and A. Pries for expert assistance in the preparation of the manuscript.

\section{References}

1. Parker SS and Vitelli T: Health care's quality improvement imperative. World Hosp Health Serv 33: 28-34, 1997.

2. White RR, Shah AS and Tyler DS: Pancreatic cancer since Halsted - how far have we come and where are we going? Ann Surg 238 (suppl 6): 132-144, 2003

3. Alexakis N, Halloran C, Raraty M, Ghaneh P, Sutton R and Neoptolemos JP: Current standards of surgery for pancreatic cancer. Br J Surg 91: 1410-1427, 2004.

4. Safioleas MC and Moulakakis KG: Pancreatic cancer today. Hepatogastroenterology 51: 862-868, 2004.

5. Magistrelli P, Antinore A, Crucitti A, La Greca A, Masetti R, Coppola R, Nuzzo G and Picciochi A: Prognostic factors after surgical resection for pancreatic carcinoma. J Surg Oncol 74: $36-40,2001$.

6. Lim JE, Chien MW and Earle CC: Prognostic factors following curative resection for pancreatic adenocarcinoma. Ann Surg 237: 74-85, 2003.

7. Trede M, Wendl K and Richter A: Pancreatic carcinoma conclusions and prospects. Langenbecks Arch Surg Suppl 115: 411-420, 1998.

8. Sperti C, Pasquali C, Piccoli A and Pedrazzoli S: Recurrence after resection for ductal adenocarcinoma of the pancreas. World J Surg 21: 195-200, 1997.

9. Kalthoff H, Schmiegel W, Roeder C, Kasche D, Schmidt A, Lauer G, Thiele HG, Honold G, Pantel K, Riethmüller G, Scherer E, Mauerer J, Maacke H and Deppert W: p53 and -ras alterations in pancreatic epithelial cell lesions. Oncogene 8: 289-298, 1993. 
10. Perugini RA, McDade TP, Vittimberga FJ Jr and Callery MP: The molecular and cellular biology of pancreatic cancer. Crit Rev Eukaryot Gene Expr 8: 377-393, 1998.

11. Deppert W, Göhler T, Koga H and Kim E: Mutant p53 'gain of function' through perturbation of nuclear structure and function. J Cell Biochem Suppl 35: 115-122, 2000.

12. Bayever E, Iversen PL, Bishop M, Sharp J, Tweary H, Arneson MA, Pirruccello SJ, Ruddon RW, Kessinger A, Zon G and Armitage J: Systemic administration of a phosphorothioate oligonucleotide with a sequence complementary to p53 for acute myelogenous leukemia and myelodysplastic syndrome: initial results of a phase I trial. Antisense Res Dev 4: 43-52, 1994.

13. Tepel J, Kruse M-L, March C, Fiedler A, Kapischke M, Ketterer T, Sipos B, Kremer B and Kalthoff H: Terminally modified oligodeoxynucleotides directed against p53 in an orthotopic xenograft model: a novel adjuvant treatment strategy for pancreatic carcinoma. Pancreas 28: 1-12, 2004.

14. Sipos B, Moser S, Kalthoff H, Torok V, Löhr M and Klöppel G: A comprehensive characterization of pancreatic ductal carcinoma cell lines: towards the establishment of an in vitro research platform. Virchows Arch 442: 444-452, 2003.

15. Moore PS, Sipos B, Orlandini S, Sorio C, Real FX, Lemoine NR, Gress T, Bassi C, Klöppel G, Kalthoff H, Ungefroren H, Löhr M and Scarpa A: Genetic profile of 22 pancreatic carcinoma cell lines. Analysis of K-ras, p53, p16 and DPC4/Smad4. Virchows Arch 439: 798-802, 2001.

16. Matzinger P: The JAM test. A simple assay for DNA fragmentation and cell death. J Immunol Methods 145: 185-192, 1991.

17. Arlt A, Vorndamm J, Breitenbroich M, Fölsch UR, Kalthoff H, Schmidt WE and Schäfer H: Inhibition of NF-kappaB sensitizes human pancreatic carcinoma cells to apoptosis induced by etoposide (VP16) or doxorubicin. Oncogene 20: 859-868, 2001. Erratum in: Oncogene 21: 2611, 2002.

18. Alves F, Borchers U, Padge B, Augustin H, Nebendahl K, Klöppel G and Tietze LF: Inhibitory effect of a matrix metalloproteinase inhibitor on growth and spread of human pancreatic ductal adenocarcinoma evaluated in an orthotopic severe combined immunodeficient (SCID) mouse model. Cancer Lett 165: 161-170, 2001.

19. Tomayko MM and Reynolds CP: Determination of subcutaneous tumour size in athymic (nude) mice. Cancer Chemother Pharmacol 24: 148-154, 1989.
20. Tepel J, Kruse M-L, Kapischke M, Haye S, Sipos B, Kremer B and Kalthoff $\mathrm{H}$ : Adjuvant treatment of pancreatic carcinoma in a clinically adapted mouse resection model. Pancreatology (In press).

21. Stein CA: The experimental use of antisense oligonucleotides: a guide for the perplexed. J Clin Invest 108: 641-644, 2001.

22. Fiedler A, Knorre C, Franke Y, Henne-Bruns D, Kremer B, Lüttges J, Maier M, Gerster M, Bleicher K, Bayer E and Kalthoff H: Growth inhibition of pancreatic tumor cells by modified anti-sense oligodeoxynucleotides. Langenbecks Arch Surg 383: 269-275, 1998 .

23. Wang W, Abbruzzese JL, Evans DB, Larry L, Cleary KR and Chiao PJ: The nuclear factor-kappa B RelA transcription factor is constitutively activated in human pancreatic adenocarcinoma cells. Clin Cancer Res 5: 119-127, 1999.

24. Arlt A, Gehrz A, Muerkoster S, Vorndamm J, Kruse ML, Fölsch UR and Schäfer H: Role of NF-kappaB and Akt/PI3K in the resistance of pancreatic carcinoma cell lines against gemcitabine-induced cell death. Oncogene 22: 3243-3251, 2003.

25. Trauzold A, Röder C, Sipos B, Karsten K, Arlt A, Jiang P, Martin-Subero JI, Siegmund D, Müerköster S, Pagerols-Raluy L, Siebert R, Wajant $\mathrm{H}$ and Kalthoff H: CD95 and TRAF2 promote invasiveness of pancreatic cancer cells. FASEB J 19: 620-622, 2005.

26. Saccani S, Pantano S and Natoli G: Modulation of NF-kappaB activity by exchange of dimers. Mol Cell 11: 1563-1574, 2003.

27. Hinz M, Krappmann D, Eichten A, Heder A, Scheidereit C and Strauss M: NF-kappaB function in growth control: regulation of cyclin D1 expression and G0/G1-to-S-phase transition. Mol Cell Biol 19: 2690-2698, 1999.

28. Heinemann V: Gemcitabine in the treatment of advanced pancreatic cancer: a comparative analysis of randomized trials. Semin Oncol 29 (suppl 20): 9-16, 2002.

29. Van Cutsem E, Aerts R, Haustermans K, Topal B, van Steenbergen W and Verslype C: Systemic treatment of pancreatic cancer. Eur J Gastroenterol Hepatol 16: 265-274, 2004.

30. Neoptolemos JP, Stocken D, Friess H, Bassi C, Dunn JA, Hickey H, Beger H, Fernandez-Cruz L, Dervenis C, Lacaine F, Falconi M, Pederzoli P, Pap A, Spooner D, Kerr DJ and Büchler M: A randomized trial of chemoradiotherapy and chemotherapy after resection of pancreatic cancer. N Engl J Med 350: 1200-1210, 2004.

31. Schneider G, Siveke JT, Eckel F and Schmid RM: Pancreatic cancer: basic and clinical aspects. Gastroenterology 128: 1606-1625, 2005 